\title{
Omalizumab for urticaria treatment in clinical practice: a case series
}

\author{
Aleksandra Lesiak ${ }^{1}$, Igor A. Bednarski ${ }^{1}$, Anna Maćkowska², Zuzanna Łukasik², Anna Woźniacka³, \\ Irmina Olejniczak-Staruch ${ }^{3}$, Joanna Narbutt ${ }^{1}$
}

${ }^{1}$ Dermatology, Pediatric Dermatology and Oncology Clinic, Medical University of Lodz, Lodz, Poland ${ }^{2}$ Student Research Group at Department of Dermatology, Medical University of Lodz, Lodz, Poland ${ }^{3}$ Department of Dermatology and Venereology, Medical University of Lodz, Lodz, Poland

Adv Dermatol Allergol 2018; XXXV (4): 372-374

DOI: https://doi.org/10.5114/ada.2018.77666

\begin{abstract}
Introduction: Omalizumab (Xolair) originally intended to reduce symptoms of moderate to severe asthma uncontrollable with steroids is the first monoclonal antibody approved for treatment of chronic spontaneous urticaria in 2014. Aim: To evaluate response and potential side effects to omalizumab treatment in clinical practice.

Material and methods: Eleven patients ( 6 males and 5 females) were recruited into the study. All participants signed written informed consent before enrollment to the study. At the beginning they were receiving $300 \mathrm{mg}$ of omalizumab in a subcutaneous injection every 4 weeks in an outpatient clinic. Five the clinical response was sufficient, the dose of omalizumab was decreased to $150 \mathrm{mg}$. We evaluated response to the treatment using the Urticaria Activity Score in the last 7 days and the Urticaria Control Test at certain time points.

Results: Nine out of 11 patients achieved complete syndrome resolution. Five patients achieved clinical remission after the first dose of omalizumab. Mean time to remission was 9.3 weeks. During the study, no side effects were observed.

Conclusions: Omalizumab appears to be a safe drug, which in a quick and effective way inducts remission in patients who have not responded to previous treatment.
\end{abstract}

Key words: urticaria, omalizumab, chronic spontaneous urticaria.

\section{Introduction}

Chronic spontaneous urticaria affects about 1\% of the population and is defined as the presence of the clinical signs of urticaria lasting for at least 6 weeks. Omalizumab (Xolair ${ }^{\oplus}$ ) was originally intended to reduce symptoms of moderate to severe asthma uncontrollable by steroids. It became the first monoclonal antibody approved for the treatment of chronic spontaneous urticaria (CSU) by the US Food and Drug Administration and the European Medicines Agency in 2014. According to the European Academy of Allergy and Clinical Immunology's guidelines on CSU, omalizumab should be used as the third line treatment after an insufficient response to the second-generation H1-blockers (antihistaminics - AH), leukotriene-receptor-antagonists (LTRA), cyclosporine A (CSA) or corticosteroids (also known as cortisone-like medicines - CLM) [1]. Omalizumab inhibits the binding of IgE to FCERI on basophils and mast cells by binding itself to Fc portion of IgE at the same place where IgE binds to FceRl. The repetitive administration of omalizumab leads to IgE depletion and down-regulation of FceRI on basophils and mast cells, which make them less sensitive to allergen stimulation. The efficacy of omalizumab has been proven in several clinical studies using 150$600 \mathrm{mg}$ doses, although data concerning omalizumab usage in clinical practice are still limited [2-7]. We present the case of 11 patients with CSU who had unsatisfactory response to the other types of the recommended treatment and began the treatment with omalizumab.

\section{Aim}

A retrospective evaluation of the response to treatment and potential side effects during omalizumab treatment in clinical practice.

Address for correspondence: Aleksandra Lesiak MD, PhD, Dermatology, Pediatric Dermatology and Oncology Clinic, Medical University of Lodz, 1/5 Kniaziewicza St, 91-347 Lodz, Poland, phone: +48 42686 79 81, e-mail: lesiak_ola@interia.pl Received: 3.04.2017, accepted: 8.06.2017. 


\section{Material and methods}

A group of 11 patients ( 6 males and 5 females) at the (mean \pm SD) age of $46.54 \pm 10.68$ were recruited into the study. All participants signed written informed consent before enrollment to the study. Median length of CSU was 23.5 months. At the beginning, they were receiving 300 mg of omalizumab (Xolair ${ }^{\bullet}$; Novartis, Basel, Switzerland) in a subcutaneous injection every 4 weeks in an outpatient clinic. If the clinical response was sufficient, the dose of omalizumab was decreased to $150 \mathrm{mg}$. We evaluated the response to the treatment using the Urticaria Activity Score in last 7 days (UAS7). The Urticaria Control Test was performed (UCT) [6] before the drug administration, after 12 weeks from the beginning of the treatment and at the end of treatment. The UAS7 rating of the severity of clinical signs ranged from 0 to 3 ( 0 - none; 1 - mild; 2 - moderate; 3 - intense, total score ranging from 0 to 6 ) and the score was a sum of the everyday scores from the previous week (maximum score -42), which was calculated by the use of patients' diaries. Whereas, the UCT evaluated the control of urticaria on a 4-point scale $(0$ - very much; 1 - much; 2-somewhat; 3 - a little; 4 - not at all); total score ranging from 0 to 16). The complete urticaria resolution was defined as UAS7 $=0$.

\section{Results}

Nine out of 11 patients achieved complete syndrome resolution. Five patients achieved clinical remission after the first dose of omalizumab. The mean time to remission was 9.3 weeks. During the study, no side effects were observed. Complete group characteristics are presented in Table 1. The changes in UAS7 and UCT scores are shown in Figures 1 and 2.

\section{Discussion}

The presented case series includes 11 patients suffering from therapy-resistant chronic urticaria. Each patient received one dose of $300 \mathrm{mg}$, which was then reduced to $150 \mathrm{mg}$ if the patient's response was satisfactory. We have proved that lowering the initial dose of omalizumab was sufficient to reduce the severity of urticaria in 9 out of 11 patients. We did not observe any side effects. Our results are consistent with other existing data about using omalizumab in CSU treatment.

Saini et al. [2] performed a multicenter, randomized, double-blinded study on 90 patients with chronic urticaria not responsive to the classical treatment. They showed the clinical efficacy after only one dose of omalizumab. A relief of symptoms compared to placebo was statis-

Table 1. Clinical characteristics of the study group

\begin{tabular}{|c|c|c|c|c|c|c|c|c|}
\hline No. & Sex/age & $\begin{array}{l}\text { Disease } \\
\text { duration }\end{array}$ & $\begin{array}{c}\text { Type of chronic } \\
\text { urticaria }\end{array}$ & $\begin{array}{l}\text { Previous } \\
\text { treatment }\end{array}$ & $\begin{array}{l}\text { Treatment duration } \\
\text { (approximated to } \\
\text { months) }\end{array}$ & $\begin{array}{l}\text { Number } \\
\text { of } 150 \mathrm{mg} \\
\text { doses }\end{array}$ & $\begin{array}{l}\text { Number } \\
\text { of } 300 \mathrm{mg} \\
\text { doses }\end{array}$ & $\begin{array}{l}\text { Time to } \\
\text { remission } \\
\text { [weeks] }\end{array}$ \\
\hline 1 & $F / 59$ & 8 months & $\begin{array}{l}\text { Pressure } \\
\text { urticaria }\end{array}$ & $\mathrm{AH}, \mathrm{CLM}$ & 14 & 14 & 0 & 4 \\
\hline 2 & $F / 32$ & 3 months & $\begin{array}{l}\text { Spontaneous } \\
\text { urticaria }\end{array}$ & $\mathrm{AH}, \mathrm{CLM}, \mathrm{LTRA}$ & 15 & 14 & 1 & 4 \\
\hline 3 & $F / 49$ & 8 years & Cold urticaria & $\begin{array}{l}\text { AH, LTRA, CSA, } \\
\text { chloroquine }\end{array}$ & 8 & 7 & 1 & 4 \\
\hline 4 & $F / 56$ & 2 years & $\begin{array}{l}\text { Spontaneous } \\
\text { urticaria }\end{array}$ & $\begin{array}{c}\mathrm{AH}, \mathrm{CLM}, \mathrm{LTRA}, \\
\text { CSA }\end{array}$ & 6 & 5 & 1 & 4 \\
\hline 5 & $F / 33$ & 31 years & $\begin{array}{l}\text { Spontaneous } \\
\text { urticaria }\end{array}$ & AH, CLM, LTRA & 12 & 11 & 1 & 52 \\
\hline 6 & $M / 60$ & 6 years & $\begin{array}{l}\text { Spontaneous } \\
\text { urticaria }\end{array}$ & $\begin{array}{l}\mathrm{AH}, \mathrm{CLM}, \mathrm{CSA}, \\
\text { azathioprine }\end{array}$ & 22 & 8 & 14 & 16 \\
\hline 7 & $M / 45$ & $\begin{array}{l}1 \text { year } \\
4 \text { months }\end{array}$ & Cold urticaria & $\mathrm{AH}$ & 7 & 2 & 5 & $\begin{array}{l}\text { No } \\
\text { remission }\end{array}$ \\
\hline 8 & $M / 60$ & 15 years & $\begin{array}{l}\text { Spontaneous } \\
\text { urticaria }\end{array}$ & AH, CLM, LTRA & 9 & 8 & 1 & 4 \\
\hline 9 & $M / 45$ & 6 months & $\begin{array}{l}\text { Spontaneous } \\
\text { urticaria }\end{array}$ & $\begin{array}{c}\mathrm{AH}, \mathrm{CLM}, \mathrm{LTRA}, \\
\text { CSA }\end{array}$ & 9 & 8 & 1 & 8 \\
\hline 10 & $M / 41$ & $\begin{array}{l}7 \text { years } \\
5 \text { months }\end{array}$ & Cold urticaria & $\begin{array}{c}\text { AH, LTRA, } \\
\text { sulfasalazine, } \\
\text { CSA }\end{array}$ & 8 & 5 & 3 & 24 \\
\hline 11 & $M / 32$ & $\begin{array}{c}1 \text { year } \\
11 \text { months }\end{array}$ & $\begin{array}{c}\text { Spontaneous } \\
\text { urticaria }\end{array}$ & $\begin{array}{c}\text { AH, CLM, LTRA, } \\
\text { CSA, azathioprine }\end{array}$ & 6 & 5 & 1 & 32 \\
\hline
\end{tabular}




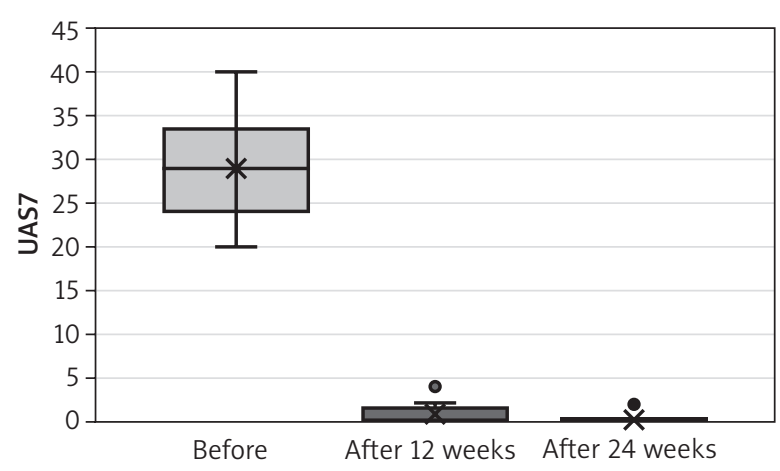

Figure 1. The UAS change during the treatment

tically significant for the dose of $300 \mathrm{mg}$ and $600 \mathrm{mg}$. There was no significant improvement after using a dose of $75 \mathrm{mg}$. After 2 weeks, a complete resolution of symptoms was achieved in $36 \%$ of patients in the $300 \mathrm{mg}$ group, $28.6 \%$ in the $600 \mathrm{mg}$ and $4.4 \%$ in the $75 \mathrm{mg}$ and $0 \%$ in the placebo group. Their results were confirmed by Maurer et al. [3] in the randomized multicenter study on 323 patients who received injections of omalizumab every 4 weeks. They observed that the dose of $300 \mathrm{mg}$ improved the course of urticaria in $44 \%$ of patients, $150 \mathrm{mg}$ in 22\%, $75 \mathrm{mg}$ in 16\% and placebo in 5\% [3].

Currently, the data on the long-term safety of omalizumab in the CSU treatment are scarce. Our study has shown that treatment with omalizumab was well tolerated and efficient in almost all patients who failed with therapy with antihistamines, corticosteroids, CSA or azathioprine. The most common side effects after omalizumab administration include allergic reactions at the injection site, a headache, a fever and abdominal pain. However, most of these reactions are mild and acceptable for the patients. The risk of serious side effects has been established between $\geq 1 / 1,000$ to $<1 / 100$. However, based on the bronchial asthma cohort studies, it can be expected that omalizumab is secure in both adults and children [8].

\section{Conclusions}

Many previous studies have shown the efficacy of omalizumab in the treatment of spontaneous urticaria. In summary, omalizumab appears to be a safe drug, which in a quick and effective way inducts remission in patients who have not responded to the previous treatment. Although omalizumab is a drug also used for other indications, the exact mechanism of action remains unknown. It should be also determined how long omalizumab should be used after achieving remission to sustain the clinical response. Another interesting issue is to identify the exact cause of treatment failure in some patients. Despite many questions and uncertainties, omalizumab should be considered in every classical treatment failures.

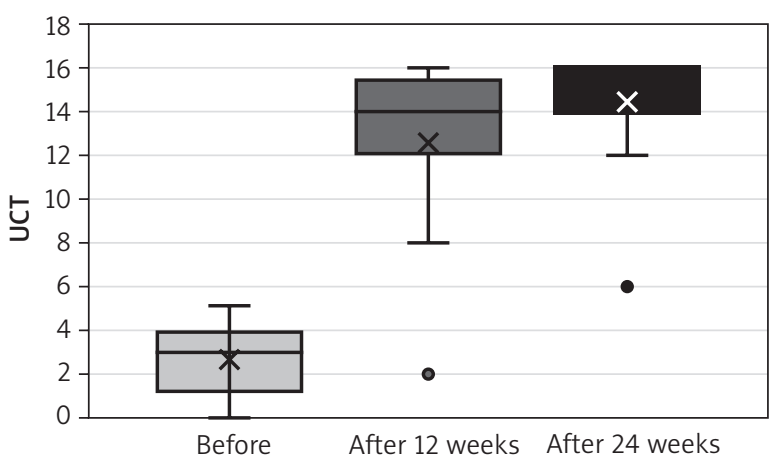

Figure 2. The UCT change during the treatment

\section{Acknowledgments}

The study was funded by Medical University of Lodz, project no. 503/1-152-01/503-01 and 503/5-064-01/503-01.

\section{Conflict of interest}

The authors declare no conflict of interest.

\section{References}

1. Zuberbier T, Aberer W, Asero R, et al. The EAACI/GA²LN/ EDF/WAO Guideline for the definition, classification, diagnosis, and management of urticaria: The 2013 revision and update. Allergy Eur J Allergy Clin Immunol 2014; 69: 868-87.

2. Saini S, Rosen KE, Hsieh HJ, et al. A randomized, placebocontrolled, dose-ranging study of single-dose omalizumab in patients with $\mathrm{H1}$-antihistamine-refractory chronic idiopathic urticaria. J Allergy Clin Immunol 2011; 128: 567-73.e1.

3. Maurer M, Rosén K, Hsieh HJJ, et al. Omalizumab for the treatment of chronic idiopathic or spontaneous urticaria. N Engl J Med 2013; 368: 924-35.

4. Bongiorno MR, Crimi N, Corrao S, et al. Omalizumab for the treatment of chronic spontaneous urticaria in clinical practice. Ann Allergy Asthma Immunol 2016; 117: 703-7.

5. Greiwe J, Bernstein JA. Therapy of antihistamine-resistant chronic spontaneous urticaria. Expert Rev Clin Immunol 2017; 13: 311-8.

6. Weller K, Groffik A, Church MK, et al. Development and validation of the Urticaria Control Test: a patient-reported outcome instrument for assessing urticaria control. J Allergy Clin Immunol 2013; 133: 1365-72.e6.

7. Sztafińska A, Jerzyńska J, Stelmach W, et al. Quality of life in asthmatic children and their caregivers after two-year treatment with omalizumab, a real-life study. Adv Dermatol Allergol 2017; 34: 439-47.

8. Gergen PJ, Mitchell HE, Gern JE, et al. Randomized trial of omalizumab (Anti-lgE) for asthma in inner-city children. N Engl J Med 2011; 364: 1005-15. 